\title{
Administrative and Legislative Scrutiny of Existing Computer Waste Management Practices in Pakistan
}

\author{
Yawar Abbas $^{1}$, Fiza Sarwar ${ }^{1,3}$, Muhammad Idrees ${ }^{1}$, Ishtiaque Hussain ${ }^{3}$, Syed Umairullah Jamil ${ }^{1}$, \\ Attarad $\mathbf{A l i}^{2,}$, \\ ${ }^{1}$ Department of Earth and Environmental Sciences, Bahria University, Islamabad, Pakistan \\ ${ }^{2}$ Department of Biotechnology, Quaid-i-Azam University, Islamabad, Pakistan \\ ${ }^{3}$ Department of Environmental Sciences, Quaid-i-Azam University, Islamabad, Pakistan
}

Email address:

attarad.ali@kiu.edu.pk (Attarad Ali)

\section{To cite this article:}

Yawar Abbas, Fiza Sarwar, Muhammad Idrees, Ishtiaque Hussain, Syed Umairullah Jamil, Attarad Ali. Administrative and Legislative Scrutiny of Existing Computer Waste Management Practices in the Twin Cities of Pakistan. American Journal of Environmental Protection. Vol. 4, No. 6, 2015, pp. 279-284. doi: 10.11648/j.ajep.20150406.13

\begin{abstract}
Electronic-waste (E-waste) management is one of the global emerging issues. The current study has been carried out to evaluate the existing computer waste management (CWM) in the twin cities of Rawalpindi and Islamabad, Pakistan. Study focuses on managerial gap analysis and determination of potential occupational impacts from current CWM practices. System observation and waste quantification are the tools used in field, while interviews and questionnaire based surveys were also conducted. The results reveal that approximately 624.15 tons of computer waste $(\mathrm{CW})$ is generated in the twin cities per year. Approximately $825 \mathrm{~kg}$ of monitors and $1125 \mathrm{~kg}$ of CPUs wastes are generated in Twin cities per day. Associated authorities like CDA, Ministry of Climate Change and EPA were interviewed for legal compliance. There is the lack of rules implementation on E-waste management. However, legislations made by concerned authorities exist in the country but are not practically enforced. Further concerns observed during the study include lack of using basic PPEs and employing child labor in their adolescence. Implementation of existing laws along with basic occupational health and safety rules in the system may play a better role to attenuate the load of waste from the very important cities of Pakistan.
\end{abstract}

Keywords: Computer Waste Management (CWM), Health and Safety, Generation, Legislation, Administration, Hazards, Electronic-Waste

\section{Introduction}

Globalization has caused people to be more connected than ever before. It has opened up innumerable economic opportunities for both post-industrialized and developing countries. It has also fashioned a commodification of electronic waste. The term electronic waste $(\mathrm{EW})$ is a generic term encompassing various forms of electrical and electronic equipment that are superannuated. EW includes discarded electronic or electric waste. Among EW, computer waste is utmost significance for being linked to socioeconomic, health, safety and environmental issues. Production of EW is growing rapidly due to the increased utilization of computers in domestic and offices. Every year, thousands of expired computers, mobile phones, television sets and radio equipment are discarded, most of which either end up in open dump site or unauthorized recycling (Saoji, 2012). In Europe it was estimated that e-waste generation was 6 million tons in 1988. In 2005 it was estimated that 8.3 and 9.1 million tons of e-waste generated. In 2020 it will increase to 12.3 million tons annually. The annual growth rate of e-waste is about 2.52.7\% (Sawhney, Henzler, Melnitzky, \& Lung, 2008) (Bashir et al., 2005).

Electronic Equipment Waste generated from non-usable or old electronics contain heavy elements that have adverse effects on the environment and human health (Asiime, E. N). Computer waste is most hazardous than other solid wastes because it contains thousands of components made up of deadly chemical and material like poly vinyl chloride (PVC, Bromated Flame, Lead, Mercury, Cadmium, Chromium, Copper ). Long term exposures to these chemicals have potential for disruption of nervous system, kidneys and bones (Saoji, 2012). Many adults get exposure Lead from the environment, so this leads to nervous system and blood 
impairments. The informal practices are due to lack of awareness (Pirzada \& Pirzada, 2010). In the United States, it was estimated that over 315 million computers would become obsolete between 1997 and 2004 and that an additional 185 million computers will become obsolete between 2004 and 2007 (Leung, Cai, \& Wong, 2006) (EPA, 1997). According to a report of Confederation of Indian Industries, the total waste generated by obsolete or broken down electronic and electrical equipment in India has been estimated to be $1,46,000$ tons per year (Joseph, 2007). The dismantling practice may be risk to the health and safety of the workers. In developing countries all the dismantling is done with the bare hand and only with the help of hammer and screw drivers (Mittal, Goel, \& Rani, 2012). Different countries around the globe have made legislation on the ewaste. Japan deals e-waste in two ways, one is law for the promotion of effective utilization of the resources (LPUR), which focuses on the recycling of the goods and reduction of the waste. The other is the recycling of home Appliances (Chung \& Murakami-Suzuki, 2008). US Congress has failed to pass Federal Legislation specially targeting either the National management or the export of e-waste. As result only two Regulations addresses on e-waste and its export, The Resource Conservation and Recovery Act 1976 (RCRA) and Environmental Protection Agency (EPA's) (Skinner, Dinter, Lloyd, \& Strothmann, 2010).

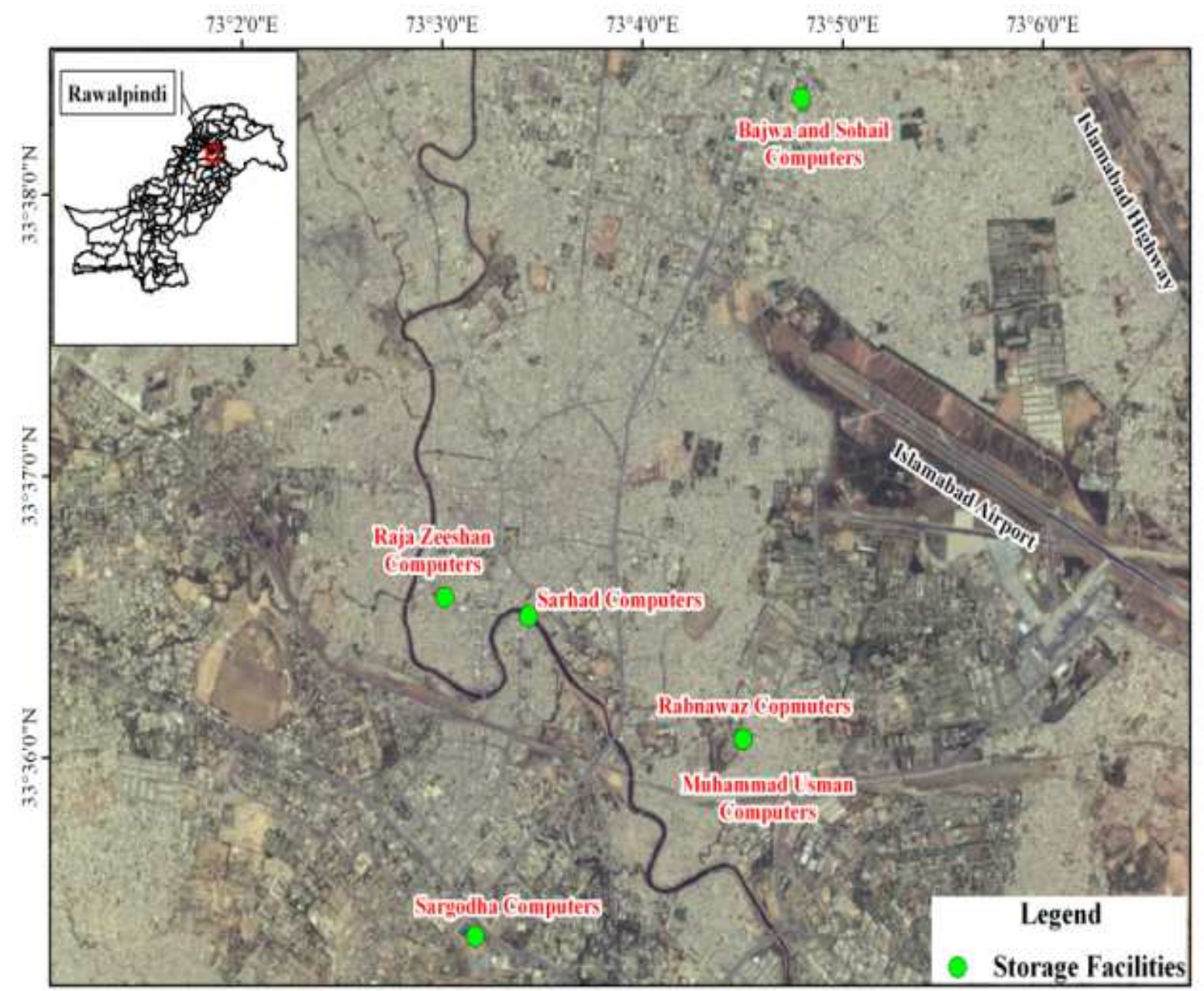

Figure 1. Site Map and Locations of Storage Facilities.

Pakistan, although has no specific legislation on e-waste import or disposal but legislations on management of hazardous substances including, Section 11, section 13 and section 14 of Pakistan Environment Protection Act, 1997, Hazardous Substance Rule 2003, National Biosafety Guidelines 2005, Import Policy Order 2003 (Bashir, et al., 2005) (Aggarwal, 2006) (EPA, 1997). Moreover, legal binding on trans-boundary movement of hazardous waste are also applicable to import of refused e-goods from developed world (Cronin et al., 2003). Pakistan is a signatory to the Basel Convention on trans-boundary movement of hazardous waste. Pakistan has huge market for the refurbished and second hand products because second hand equipment's is affordable for majority. Most of second equipment's brought to the Pakistan. Many times waste send to Pakistan as donation for the Government Schools. Pakistan is the third largest importer of e-waste or third waste dump fill site (Umair, Björklund, \& Petersen, 2013).

The computers and other obsolete electronic goods are however imported under the pretext of 'second-hand equipment'. Barely a small percentage of the items imported are usable. In practice, after removing the working machines 
and usable parts the bulk of the consignment is sent to the recycling industry (Umair, Björklund, \& Petersen, 2015). This is how fundamentals of Basal Convention are ignored (Pirzada \& Pirzada, 2010). The mismanaged e-waste results in circulation of health hazards into the environmental matrices rendering the life more helplessly vulnerable (Godwin, 1993).

\section{Materials and Methods}

Study Area

The current research was designed and carried out for the assessment of computer waste management (CWM), administrative structure, occupational safety and legislative gaps analysis of management practices for the Computer Waste in Rawalpindi and Islamabad. Research focused on the generation of $\mathrm{CW}$ in the storage facilities. The area of twin cities is famous for the computer business. The area was chosen because here, the computer industry flourishes day by day with addition of new technology (see figure 1).
Data was collected through study of existing CWMS employing 'walk through survey' as a tool. Moreover, quantification of computer waste was done through onsite weighing. The extant information is collected through weighing of the computer waste in the storage areas and closely observing the management practice of $\mathrm{CW}$ for the period of seven months (January 2014-July 2014). For the ease of interpretation, codes are assigned to the $\mathrm{CW}$ handling facilities (see table 3).

Table 1. Parameters for data analysis.

\begin{tabular}{ll}
\hline s/no & Parameters \\
\hline 1 & Legislative Framework \\
2 & CW/EW Management System \\
3 & Responsible Authority \\
4 & Role of Government Bodies \\
5 & Public Private Partnership \\
6 & Occupational Hazards in CWM \\
\hline
\end{tabular}

Table 2. Role and Responsibilities of Government Organizations.

\begin{tabular}{|c|c|c|c|}
\hline s/no & Organization & $\begin{array}{l}\text { Parameters for investigation of } \\
\text { responsibilities and current works }\end{array}$ & Justification \\
\hline 1 & $\begin{array}{l}\text { CDA (Capital Development } \\
\text { Authority) }\end{array}$ & CWM & CDA is working in Islamabad for waste management \\
\hline 2 & $\begin{array}{l}\text { MoCC (Ministry of Climate } \\
\text { Change) }\end{array}$ & $\begin{array}{l}\text { Legislation and management } \\
\text { Practices }\end{array}$ & $\begin{array}{l}\text { MoCC is working for the safeguard of environment and } \\
\text { formulation of laws }\end{array}$ \\
\hline 3 & $\begin{array}{l}\text { Pak-EPA (Pakistan Environment } \\
\text { protection Agency) }\end{array}$ & $\begin{array}{l}\text { Legislation and management } \\
\text { Practices }\end{array}$ & $\begin{array}{l}\text { Pak-EPA is regulatory body for implementation of laws and } \\
\text { management practices }\end{array}$ \\
\hline 4 & Provincial EPA & Waste management & To acquire data on the CWM \\
\hline
\end{tabular}

Table 3. Generation of $C W$ in Rawalpindi-Islamabad.

\begin{tabular}{|c|c|c|c|c|c|c|c|c|}
\hline $\mathbf{s} / \mathbf{n}$ & $\begin{array}{l}\text { Name of } \\
\text { Facility } \\
\end{array}$ & Location & Type of Waste & $\begin{array}{l}\text { Generation of } \\
\text { CW per day }\end{array}$ & $\begin{array}{l}\text { Generation of } \\
\text { CW weekly }\end{array}$ & $\begin{array}{l}\text { Generation of } \\
\text { waste Monthly }\end{array}$ & $\begin{array}{l}\text { Annual } \\
\text { Generation }\end{array}$ & $\begin{array}{l}\text { Code of } \\
\text { facility }\end{array}$ \\
\hline 1 & $\begin{array}{l}\text { Bajwa } \\
\text { Computers }\end{array}$ & $\begin{array}{l}6^{\text {th }} \text { Road } \\
\text { Rawalpindi }\end{array}$ & $\begin{array}{l}\text { Monitor Waste } \\
\text { CPU Waste } \\
\text { Total Waste }\end{array}$ & $\begin{array}{l}150-200 \mathrm{~kg} \\
230 \mathrm{~kg} \\
390 \mathrm{~kg}\end{array}$ & $2730 \mathrm{~kg}$ & $\begin{array}{l}10920 \mathrm{~kg} \\
\text { (10.920 tons) }\end{array}$ & $\begin{array}{l}142350 \mathrm{~kg} \\
(142.350 \text { tons })\end{array}$ & $\mathrm{a}$ \\
\hline 2 & $\begin{array}{l}\text { Sohail } \\
\text { Computer }\end{array}$ & $\begin{array}{l}6^{\text {th }} \text { Road } \\
\text { Rawalpindi }\end{array}$ & $\begin{array}{l}\text { Monitor Waste } \\
\text { CPU Waste } \\
\text { Total Waste }\end{array}$ & $\begin{array}{l}50-100 \mathrm{~kg} \\
100-150 \mathrm{~kg} \\
230 \mathrm{~kg}\end{array}$ & $1610 \mathrm{~kg}$ & $\begin{array}{l}6440 \mathrm{~kg} \\
(6.440 \text { tons })\end{array}$ & $\begin{array}{l}83950 \mathrm{~kg} \\
(83.950 \text { tons })\end{array}$ & $\mathrm{b}$ \\
\hline 3 & $\begin{array}{l}\text { Sarghoda } \\
\text { Computer }\end{array}$ & $\begin{array}{l}\text { Sadar, } \\
\text { Rawalpindi }\end{array}$ & $\begin{array}{l}\text { Monitor Waste } \\
\text { CPU Waste } \\
\text { Total Waste }\end{array}$ & $\begin{array}{l}50-100 \mathrm{~kg} \\
150-200 \mathrm{~kg} \\
240 \mathrm{~kg}\end{array}$ & $1680 \mathrm{~kg}$ & $\begin{array}{l}6720 \mathrm{~kg} \\
(6.720 \text { tons })\end{array}$ & $\begin{array}{l}87600 \mathrm{~kg} \\
(87.600 \text { tons })\end{array}$ & $\mathrm{c}$ \\
\hline 4 & $\begin{array}{l}\text { Rabnawaz } \\
\text { Computer }\end{array}$ & $\begin{array}{l}\text { Tipu Road, } \\
\text { Rawalpindi }\end{array}$ & $\begin{array}{l}\text { Monitor Waste } \\
\text { CPU Waste } \\
\text { Total Waste }\end{array}$ & $\begin{array}{l}50-100 \mathrm{~kg} \\
150-200 \mathrm{~kg} \\
250 \mathrm{~kg}\end{array}$ & $1750 \mathrm{~kg}$ & $\begin{array}{l}7000 \mathrm{~kg} \\
\text { ( } 7 \text { tons) }\end{array}$ & $\begin{array}{l}91250 \mathrm{~kg} \\
\text { (91.250 tons) }\end{array}$ & $\mathrm{d}$ \\
\hline 5 & $\begin{array}{l}\text { Usman } \\
\text { Computer }\end{array}$ & $\begin{array}{l}\text { Tipu Road, } \\
\text { Rawalpindi }\end{array}$ & $\begin{array}{l}\text { Monitor Waste } \\
\text { CPU Waste } \\
\text { Total Waste }\end{array}$ & $\begin{array}{l}50-100 \mathrm{~kg} \\
100-150 \mathrm{~kg} \\
200 \mathrm{~kg}\end{array}$ & $1400 \mathrm{~kg}$ & $\begin{array}{l}5600 \mathrm{~kg} \\
\text { (5.6 tons) }\end{array}$ & $\begin{array}{l}73000 \mathrm{~kg} \\
(73 \text { tons })\end{array}$ & e \\
\hline 6 & $\begin{array}{l}\text { Raja Zeeshan } \\
\text { Computer }\end{array}$ & $\begin{array}{l}\text { Raja Bazar, } \\
\text { Rawalpindi }\end{array}$ & $\begin{array}{l}\text { Monitor Waste } \\
\text { CPU Waste } \\
\text { Total Waste }\end{array}$ & $\begin{array}{l}50-100 \mathrm{~kg} \\
50-100 \mathrm{~kg} \\
150 \mathrm{~kg}\end{array}$ & $1050 \mathrm{~kg}$ & $\begin{array}{l}4200 \mathrm{~kg} \\
(4.2 \text { tons })\end{array}$ & $\begin{array}{l}54750 \mathrm{~kg} \\
\text { (54.750 tons) }\end{array}$ & $\mathrm{f}$ \\
\hline 7 & $\begin{array}{l}\text { Sarhad } \\
\text { Computer }\end{array}$ & $\begin{array}{l}\text { Gawalmandi } \\
\text { Rawalpindi }\end{array}$ & $\begin{array}{l}\text { Monitor Waste } \\
\text { CPU waste } \\
\text { Total Waste }\end{array}$ & $\begin{array}{l}100-150 \mathrm{~kg} \\
100-150 \mathrm{~kg} \\
250 \mathrm{~kg}\end{array}$ & $1750 \mathrm{~kg}$ & $\begin{array}{l}7500 \mathrm{~kg} \\
\text { (7.500 tons) }\end{array}$ & $\begin{array}{l}91250 \mathrm{~kg} \\
(91.250 \text { tons }) \\
6624.15 \text { tons }) \\
\end{array}$ & $\mathrm{g}$ \\
\hline
\end{tabular}

For compliance assessment questionnaire based surveys and interviews were carried out. The random sampling includes workforce (30 respondents), storage facility owners (07 respondents) and competent authorities (06) separately. The C.W generation and disposal practices (the
Administrative framework) are correlated with the existing legal framework. The gap analysis is done on the basis of six selected parameters tabulated in table 1, however table 2 presents the competent authorities surveyed to evaluate the management system responsibilities and legal compliance. 


\section{Results and Discussions}

\subsection{Computer Waste Quantification}

The best possible mean of computer waste quantification, i.e. 'on-site weighing' was chosen for the purpose. In RawalpindiIslamabad there are seven storage facilities classified as a, b, c, $\mathrm{d}$, e, f and $\mathrm{g}$ in table 3 . On average, the facility (a) receives $150-200 \mathrm{~kg}$ of monitor waste on daily basis. On the other side facility (g) receives $100-150 \mathrm{~kg}$ waste per day. Facilities (b, c, $\mathrm{d}$, e and f) receive $50-100 \mathrm{~kg}$ of monitor waste per day.

According to the facility classification shown in table 3 , the facility (a) receives $200-250 \mathrm{~kg}$ of CPU waste per day. The amount of CPU fluctuates on daily basis. Facility (b, e and g) receive 100-150 CPU waste per day. Facility (c and d) receive $150-200 \mathrm{~kg}$ on daily basis while, facility (f) receives $50-100 \mathrm{~kg}$ of CPU waste. Most of the CPU waste is being sold in the markets due to advancement of technologies day by day and people prefer to buy new technologies.

Approximately 624.15 tons of $\mathrm{CW}$ generates in the Rawalpindi-Islamabad annually. $57 \%$ of storage owners receive 51-100 tons, $28.6 \% 1-50$ tons of $\mathrm{CW}$ annually and $14.3 \%$ of storage facilities receive $101-150$ tons of $\mathrm{CW}$ annually. This variation among facilities depends not only on size of storage facilities but also the areas from where the computer waste is brought to them.

According to system observation, on average, $49 \%$ of storage facilities send $1-50 \mathrm{~kg}$ of $\mathrm{CW}$ for recycling per day. About $28.6 \%$ of facilities send $50-100 \mathrm{~kg}$ of $\mathrm{CW}$ for recycling and further processing. $14.3 \%$ of storage facilities send $150-200 \mathrm{~kg} .14 .3 \%$ of facilities send more than $200 \mathrm{~kg}$ of waste for recycling per day.

Through system examination it is found $57.1 \%$ of storage facilities send 1-50 tons of CW for recycling annually. While $14.3 \%$ of facilities sent $50-100$ tons of $\mathrm{CW}$. $14.3 \%$ of facilities send 100-150 tons. Moreover $14.3 \%$ sent 150-200 tons of $\mathrm{CW}$ for recycling annually. The fluctuations in quantities are always expected depending on the advancement in technology and resulting increase or decrease in lots of rejected goods received from developed world (Umair, et al., 2015).

\subsection{Legislative and Administrative Evaluation}

The core elements of waste management system i.e. quantification, segregation, management and disposal are found to be virtually absent in Rawalpindi and Islamabad. The private sector plays key role for the management of the computer waste. No government agency is involving in the CWM. There are no criteria for waste segregation for reuse and recycling in the system. The storage and dismantling facilities exist but there is no recycling facility for the $\mathrm{CW}$ (Umair, et al., 2015). The whole computer waste management system $(\mathrm{CWM})$ is operated by private and no public participation has been recorded.

The system analysis revealed that the CWM process is operating by storage owners without license. Moreover, the informal and unauthorized owners of the facilities do not have license of handling, treatment and transportation of hazardous waste. A proper landfill for the hazardous waste is missing in the Rawalpindi-Islamabad. In Hazardous waste Rules 2003, it is mandatory to get license for handling and treatment of hazardous material. The informal handling and treatment of the hazardous waste may lead towards the worse condition for the health of work force and environment (Cronin, et al., 2003).

Pakistan has signed Basal Convention on Hazardous waste. The e-waste contains hazardous substances and majority of the e-waste being imported from the developed countries (Godwin, 1993). It is mandatory for every country that has signed convention to recycle their waste in their jurisdiction (Umair, et al., 2015). The work forces in the facilities are prone to the health and safety risks. Majority of CW being generated is in the form of second hand computer which is donated by developed countries. This leads to burden of computer waste in the country.

Capital development authority (CDA) and Rawalpindi development authority (RDA) that are responsible for solid waste management in the twin cities, have not devised some management for e-waste so far. Although the environmental and occupational hazards of computer waste handling and disposal are known, the waste is being dealt with as municipal waste, i.e. non-hazardous solid waste. Unfortunately the government agencies did not ever arrange any awareness campaign for the workers.

As far as the role of Pakistan Environment Protection Agency (EPA) is concerned, Sindh-EPA and Gilgit-Baltistan EPA has formulated legislation on computer waste management (CWM) but Federal administration and Punjab EPA have not taken such an initiative yet. This is probably due to lack of data and improper system. No doubt the hidden unlawful handling of hazardous materials and lack of awareness of local dealers and traders on associated environmental and health issues are the guilty parts of the picture.

\subsection{Occupational Health and Safety}

The workforce belonging to almost all age groups is involved in CWM process. Although $9.09 \%$ belong to the age group of $10-15$ years, $27.3 \%$ fall in age group 16-20 years. $9.09 \%$ workers are $21-25$ years, while $27.3 \%$ are $26-30$ years and $27.3 \%$ fall in age group of more than 30 years, working in CWM. Teenagers are engaged in the dismantling of $\mathrm{CW}$ without protective measures. Teenagers are working in this industry due to lack of job opportunities and education. Section 3 of the Employment of Children Act (ECA), 1991 bans employment of children under-14 in occupations connected with hazardous labor works that seems being widely not complied with in this industry (Fasih, 2007). Majority of the work force involved in the CWM are having primary level. A very small percentage of work forces are only secondary school qualified.

The Chapter 3 of Factories Act, 1934, talks about various safety arrangements at work place including provision of personal protective equipment and safe working conditions. Through system surveillance, it is determined that the 
personnel engaged in computer waste handling, transporting, dismantling and recycling are unaware of health hazards associated with their work (Umair, et al., 2015). There is no concept of personal protective equipment (PPEs). None of them found to be using PPEs or taking any precautionary measure during dismantling specially. This non-compliance is not an issue of one industrial unit but a matter of overall system ignorance on existing legal framework.

\section{Recommendations}

- Government agencies may pay keen attention to solve this problem with the collaboration of non-government organization (NGO).

- The proper training may be conducted for those who are directly involved in this profession in order to enhance the technical expertise of the work force.

- Government may develop a monitoring system to minimize Second hand computers donated by the developed nation to the Government Schools and institutions.

- Basal convention may implement formally to stop illegal import of hazardous waste in the country.

- Compliance of Child labor Act may ensure in this profession, most of dismantling of the computer waste is done by the teenagers.

- The Government of Pakistan may raise the education level among the children.

- Responsible authorities related to environment may ensure hazardous substance rules.

- Section 13 and section 14 if PEPA may enact where there is computer waste handling and dismantling

- CWM may be centralized and implementation of the polluter pays principle and there may a monitoring system for the better management.

- Ministry of Commerce may be directly involved for the management of the electronic waste.

- OHS policies may be implemented in this occupation for the minimal injuries.

- Use of alternate material and equipment having fewer hazards may be beneficial for the workers who are associated with CWM.

\section{Conclusion}

The overall CW-management is under the unofficial and informal organizations. Computer waste management (CWM) in Rawalpindi-Islamabad is a difficult task, if the Government Agencies do not adopt a pragmatic approach. The computer waste contains hazardous material and may pose a risk to the human health and environment. There exists an urgent need for the detail assessment of existing and future scenarios including generation, characteristics, existing disposal practices and environmental impacts. Institutions need to develop mechanism for collection, transportation, storage, segregation recycling, reuse and treatment of computer waste. Institutions which are engaged in the environmental services do not have any accurate data on generation of computer waste in Islamabad and disposal of computer waste. In short, instead of focusing on nonexistence of a direct law on the subject, the need of the hour is to bridge the gaps between existence of indirect legislation and its proper compliance. This includes the issues of import, marketing of computer waste and occupational safety as well. The concerned administrative and legislative competent authorities need to focus on the issue before it gets complicated. In this regard, current case-study may be used as an initial authentic information to start with. Furthermore, the competent authorities with the help of Environmental Tribunals may conduct environmental, occupational safety and legal audits to ensure sustainable practices in the area.

\section{References}

[1] Aggarwal, A. (2006). Special economic zones: revisiting the policy debate. Economic and Political Weekly, 4533-4536.

[2] Bashir, K., Husnain, T., Fatima, T., Riaz, N., Makhdoom, R., \& Riazuddin, S. (2005). Novel indica basmati line (B-370) expressing two unrelated genes of Bacillus thuringiensis is highly resistant to two lepidopteran insects in the field. Crop protection, 24(10), 870-879.

[3] Chung, S.-W., \& Murakami-Suzuki, R. (2008). A comparative study of e-waste recycling systems in Japan, South Korea and Taiwan from the EPR perspective: implications for developing countries. Kojima. Chiba.

[4] Cronin, M. T., Jaworska, J. S., Walker, J. D., Comber, M. H., Watts, C. D., \& Worth, A. P. (2003). Use of QSARs in international decision-making frameworks to predict health effects of chemical substances. Environ. Health Perspect., 111(10), 1391.

[5] EPA, P. (1997). Pakistan Environmental Protection Act, 1997. Government of Pakistan, Ministry of Environment. 25p.

[6] Fasih, T. (2007). Analyzing the impact of legislation on child labor in Pakistan (Vol. 4399): World Bank Publications.

[7] Godwin, D. L. (1993). Basel Convention on Transboundary Movements of Hazardous Wastes: An Opportunity for Industrialized Nations to Clean up Their Acts, The. Denv. J. Int'l L. \& Pol'y, 22, 193.

[8] Joseph, K. (2007). Electronic waste management in Indiaissues and strategies. Paper presented at the Eleventh International Waste Management and Landfill Symposium, Sardinia.

[9] Leung, A., Cai, Z. W., \& Wong, M. H. (2006). Environmental contamination from electronic waste recycling at Guiyu, southeast China. Journal of Material Cycles and Waste Management, 8(1), 21-33.

[10] Mittal, D., Goel, N., \& Rani, R. (2012). E-Waste: A Hidden Threat to Global Environment and Health. VSRD International Journal of Science and Technology, 2(3), 271-275.

[11] Pirzada, M. D. S., \& Pirzada, F. N. (2010). E-Waste: An Impending Challenge. Pakistan Institute of Nuclear Science \& Technology. 
[12] Saoji, A. (2012). E-Waste Management: An Emerging Environmental and Health Issue in India. National Journal of Medical Research, 2(1), 107-110.

[13] Sawhney, P., Henzler, M., Melnitzky, S., \& Lung, A. (2008). Best practices for E-waste Management in Developed Countries. Adelphi Research, Austria.

[14] Skinner, A., Dinter, Y., Lloyd, A., \& Strothmann, P. (2010). The Challenges of E-Waste Management in India: Can India draw lessons from the EU and the USA. ASIEN, 117, 7-26.
[15] Umair, S., Björklund, A., \& Petersen, E. E. (2013). Social life cycle inventory and impact assessment of informal recycling of electronic ICT waste in Pakistan. Paper presented at the Hilty L, Aebischer E, Andersson G, Lohmann W, Proceedings of the First International Conference on Information and Communication Technologies for Sustainability ETH Zurich.

[16] Umair, S., Björklund, A., \& Petersen, E. E. (2015). Social impact assessment of informal recycling of electronic ICT waste in Pakistan using UNEP SETAC guidelines. Resources, Conservation and Recycling, 95, 46-57. 